\title{
TATA RIAS PENGANTIN AGUNG JEMBRANA
}

\author{
Kadek Hermayani ${ }^{1}$, Ni Ketut Widiartini ${ }^{2}$, Made Diah Angendari ${ }^{3}$ \\ Program Studi Pendidikan Kesejahteraan Keluarga, Fakultas Teknik dan Kejuruan \\ Universitas Pendidikan Ganesha \\ Singaraja, Indonesia \\ e-mail: kadekhermayani08@gmail.com, ketut.widiartini@undiksha.ac.id, \\ diah.angendari@undiksha.ac.id
}

\begin{abstract}
Abstrak
Penelitian ini bertujuan untuk mendeskripsikan tata rias pengantin Agung Jembrana, fungsi dan makna tata rias pengantin Agung Jembrana. Jenis penelitian ini adalah deskriptif kualitatif. Lokasi penelitian di LKP W \& W Asri. Metode yang digunakan adalah metode observasi dan wawancara. Instrument penelitian berupa lembar observasi dan pedoman wawancara. Hasil penelitian tata rias pengantin agung Jembrana yang berbeda pada umumnya terdiri dari (a) tata rias wajah meliputi: serinata dan alis-alis (b) tatanan rambut pengantin wanita meliputi: bunga menori putih, bunga menori kuncup putih dan sanggul gelung tanduk. Pada pengantin pria meliputi: udeng. (c) busana pengantin wanita meliputi: tapih wali, kamen songket, selendang bersulam benang emas, selendang cerari dan baju bludru hitam. Pengantin pria meliputi: kamen mastuli penuh, saput songket, umpal cerari dan baju bludru hitam. (d) aksesoris pengantin wanita meliputi: subeng, sabuk pending, gelang nagasatru dan kalung binar. Pengantin pria meliputi: rumbing, gelang nagasatru dan gelang kaki, keris dan pucuk emas.
\end{abstract}

Kata Kunci: Fungsi, Makna, Tata Rias, Pengantin Agung, Kabupaten Jembrana

\begin{abstract}
This study aimed at describing the bridal makeup of Agung Jembrana, the meaning and function of the bridal makeup of Agung Jembrana. This study employed descriptive qualitative research. The research location of this study was at LKP W \& W Asri. This study used observation and interview method for collecting the data. The research instruments were observation sheet and interview guidelines. The results indicated that, the bridal makeup of Agung Jembrana consisted of (a) makeup, included: serinata, eyebrows. (b) the bride's hairdo, included: white menori flower, bud-white menori flower, and sanggul gelung tanduk. Meanwhile, the groom, included: udeng. (c) bridal gowns, included: tapih wali, kamen songket, scarves embroidered by gold thread, cerari scraves, black velvet shirt. The groom, included: full of kamen mastuli, saput songket, umpal cerari, and black velvet shirt. (d) bridal accessories, included: subeng, pending belt, naga satru bracelets, and binar necklace. The groom, included: rumbing, naga satru bracelets and anklets, keris, and the flower put on the udeng.
\end{abstract}

Key Word: Function, Mean, Great Bridal Makeup Agung. Regency, Jembrana 


\section{PENDAHULUAN}

Pernikahan merupakan upacara yang sangat sakral dan dilakukan sesuai dengan tata cara laksananya yang dilakukan oleh dua orang (sepasang) yang akan disahkan menjadi suami istri. Pada saat melangsungkan pernikahan sebagian besar akan menggunakan tata rias baik digunakan pada wanita maupun pria. Tata rias yang digunakan pada saat melangsungkan pernikahan merupakan peninggalan oleh nenek moyang terdahulu baik itu tata rias wajah, busana maupun aksesoris yang merupakan peninggalan nenek moyang terdahulu dan digunakan pada acara pernikahan yang sakral.

Bali merupakan pulau seribu pura dimana Bali masih kental dengan seni dan budaya yang sudah dijadikan sebagai ciri khas tersendiri. Bali memiliki 8 Kabupaten. Dimana setiap kabupatan memiliki ciri khas tersendiri pada tata rias yang digunakan sesuai adat dan istiadat dari daerah tersebut. Tata rias pengantin ini merupakan peninggalan nenek moyang terdahulu yang tidak dapat ditinggalkan karena nenek moyang terdahulu membuat pakem tata rias sesuai dengan makna dan fungsi dari setiap bagiannya. Pada zaman dahulu tata pengantin Agung hanya boleh digunakan oleh kalangan kerajaan, tetapi dengan berkembangnya zaman yang sudah modern ini tata rias pengantin Agung sudah boleh digunakan oleh masyarakat. Tata rias pengantin Agung Bali identik dengan menggunakan aksesoris keemasan. Tata rias dan busana pengantin Gaya Badung memiliki tiga tingkatan yaitu: tata rias dan busana pengantin nista (sederhana), madya (menengah) dan utama itu tata rias yang paling tinggi dengan menggunakan gelung agung. Menurut puji dwiastuti (2016) dengan tata rias pengantin Gaya Badung yang memiliki banyak tingkatan pada tata riasnya. Selanjutnya di Kabupaten Karangasem pun memiliki tata rias pengantin Agung yang terlihat sangat unik dengan memiliki ciri khas tersendiri. Tata rias pengantin Agung Karangasem menggunakan selendang bangsingan yang dibuat dengan cara ditenun, menggunakan empak-empak sebagai tatanan rambutnya Ni Kadek Lina Wiartini (2016). Kabupaten Buleleng juga memiliki ciri khas tersendiri pada tata rias pengantinnya yang dapat dilihat dari busananya menggunakan kencrik kesir merah tipis yang digunakan pada bahu pengantin wanita di bentuk segitiga Rizki Ari Safitri (2017). Dari tata rias yang sudah ada menyatakan bahwa setiap kabupaten memiliki ciri khas tersndiri yang menonjol pada tata rias pengantinnya.

Pada Kabupaten Jembrana pun memiliki ciri khas yang sangat menonjol yang terlihat sangat unik. Tata rias pengantin Agung Jembrana memiliki ciri khas pada bagian tata rias wajah yang menggunakan semi capit udang, pada tatanan rambut yaitu menggunakan sanggul gelung tanduk. Pada busana pun sangat berbeda dengan di kabupaten lain dimana pada tata rias pengantin Agung Jembrana busana yang digunakan yaitu songket tenunan khas Jembrana sehinga terlihat sangat berbeda dengan tata rias di kabupaten lain.

Menurut Mila Noviana (2015) mengatakan bahwa tata rias wajah adalah kebutuhan utama bagi wanita khususnya dengan menggunakan kosmetik tentunya akan membuat mereka lebih percaya diri dan selalu tampil menarik di setiap harinya. Tata rias pengantin adalah tata yang digunakan untuk pengantin. Tata rias pengantin harus memiliki kekuatan untuk merubah wajah lebih berseri dan tampak istimewa dengan tetap mempertahankan kecantikan alami yang bersifat personal dengan tujuan mempercantik wajah, membuat wajah lebih terlihat ceria dan angun serta mengimbangi dengan keadaan sebuah pesta pernikahan. Tata rias merupakan cara atau usaha seseorang untuk mempercantik diri khususnya pada bagian wajah atau muka, menghias diri dalan pergaulan (Serinati, 2011). Tata rias pengantin agung Gaya Badung adalah tata rias pengantin yang berasal dari kerajaan Badung, nuansa ningrat begitu kental terasa pada busana dan tata rias pengantin Bali payas agung Badung atau disebut juga Bali Agung. Susunan 
perhiasan bernuansa keemasan cantik memahkotai pengantin wanita juga pengantin pria. Ayunya semakin cantik dengan serinata dan lengkungan simetris di dahi, selaras dengan petitis dan sepasang tajug emas yang disematkan di atasnya. Seakan melengkapi keindahan yang tercipta dengan susunan bunga sandat yang ditutupi bunga kap emas, hadir begitu indah memahkotai sang pengantin wanita. (11 Desember 2018 httpps://www.weddingku.com).

Tata rias wajah pengantin Agung Bali terdiri dari: serinata, gecek, alis-lais, eyehadow, lipstick dan shading. Langkah dalam merias wajah sebagai berikut:

1. Bersihkan wajah dengan menggunakan milk cleanser dan penyegar sebagai penutup pori-pori kulit wajah.

2. Aplikasikan pelembab, foundution, dan bedak tabur.

3. Buat alis dengan warna hitam kecoklatan

4. Aplikasikan eyeshadow sesuai dengan kesemapatan, kemudian pasang bulu mata

5. Aplikasikan eyeliner atas dan bawah dengan warna eyeliner hitam

6. Aplikasikan perona pipi dan terakhir aplikasikan lipstik.

Penataan rambut adalah suatu proses tahap akhir dimana penataan rambut sangat terpenting karena penataan rambut juga sangat mendukung dalam berpenampilan. Menurut (Mertami, 1993:25) penataan rambut pada tata rias pengantin agung Bali ini dinamakan "semi". Semi merupakan bentuk bagian depan yang mencirikan bahwa dari tata rias pengantin agung Bali. Dimana semi ini akan diberi malem untuk memperkuat bentuk dari semi tersebut. Bentuk semi ini disebut dengan engkug-engkugan (sunggar) yang bentuknnya kedalam menuju kebelakang telinga. Tatanan rambut pada tata rias pengantin agung diantaranya: pusung tagel, gelung kucit, bunga sandat, bunga cempaka putihkuning, bunga emas dan bunga mawar.
Tata busana sebagai bagian dari tata rias dalam pengantin umumnya, masingmasing kabupaten mempunyai busana pengantin tersendiri dengan makna dan keunikan serta seni yang amat indah (Mertami, 1993:14). Busana pengantin agung Bali merupakan busana yang digunakan untuk pengantin tata rias agung Bali yang terdiri dari: a) pengantin wanita terdiri dari: tapih, kamen/wastra, sabuk/stagen, selendang. b) pengantin pria terdiri dari: kamen, kampuh, umpal dan udeng. Aksesoris merupakan bendabenda yang dikenakan seseorang untuk mendukung atau menjadi penganti pakaian (menurut Wikipedia). Pada tata rias pengsntin agung Bali memiliki aksesori. a) pengantin wanita yang terdiri dari petitis, badong, sabuk pending, subeng cerorot, gelang. b) petitis, tajug, garuda mungkur, gelang kana, gelang nagasatru keris dan badong. Pada tata rias pengantin Bali identik dengan menggunakan hiasan dahi yang dinamakan dengan serinata. Serinata di buat pada dahi seorang pengantin wanita dengan menggunakan ukuran tertentu dan sesuai dengan bentuk wajah seseorang. Mewarnai serinata hanya boleh menggunakan pensil alis hitam. Berikut tahapan membuat serinata: pertama buat titik ditengah-tengah garis pertumbuhan rambut didahi, sejajar dengan gecek atau bangket, dari titik ini ukur kekiri dan kenanan selebar 2 jari. Dari titik kanan ke titik kiri yang garisnya melengkung dan bulat kedalam, dari titik alis, ukur ke atas selebar ibu jari agak ditekan, selanjutnya hubungkan titik yang telah dibuat di atas. dengan melukis garis lengkung keluar agak landai, setelah serinata terbentuk, lalu periksa lagi dengan baik, simetrisnya kiri kanan dilihat, agar bentuknya seimbang.

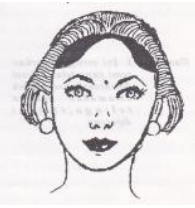

Gambar 1. Serinata

(Sumber: Mertami, 1993:28)

Tatanan rambut pada tata rias pengantin Agung Bali identik dengan 
menggunakan semi, dimana semi ini di buat dengan bantuan malem yang diaplikasikan pada rambut yang nantinya akan dibentuk di belakang telinga. Pembuatan semi dimulai dari buatlah belahan rambut ditengah-tengah kepala depan, ambil serong dari belahan depan kekiri dan kekanan (menyerupai tanda ?) menuju ke belakang telinga, mengambil rambut serong dari depan tidak boleh terlalu kedalam atau terlalu keluar, dapat dikira-kira selebar tiga jari dari garis rambut depan dibagian atasnya, Ialu kebawah, mengikuti garis rambut menuju kebelakang telinga, sisa rambut dibelakang di sisier ke atas dengan ukuran 7 - 8 jari dari garis depan, setelah garisnya dibentuk lalu di beri malem sambil dibentuk.

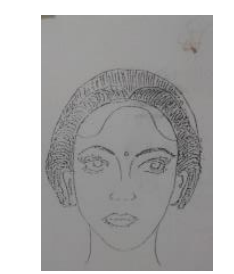

Gambar 2. Semi

(Sumber: Mertami, 1993:28)

Fungsi merupakan suatu hal yang memiliki kegunaaan berdasarkan benda atau pekerjaan yang dilakukan sesuai dengan bentuk dan penempatan dari benda tersebut. Begitu juga pada tata rias pengantin Agung Bali memiliki fungsi setiap bentuk dari masing-masing bagiannya yang terdiri dari tata rias wajah, tatanan rambut, busana dan aksesorisnya. Fungsi tata rias wajah diantaranya menutupi kekurangan yang ada pada wajah dan dapat menonjolkan kelebihannya, dapat mempercantik diri dan dapat memperlihatkan karakter dari tata rias tersebut. Fungsi tatanan rambut sebagai memperbaiki dan mempercantik penampilan dengan tatanan rambut yang rapi, indah dan mempesona. Tatanan rambut dapat menandakan bahwa seseorang memiliki profesi dan keahlian tersendiri. Selain dapat mempercantik penampilan tatanan rambut ini dapat menonjolkan ciri khas suatu riasan salah satunya tata rias pengantin Agung Bali dengan tatanan rambut menggunakan sanggul pusung tagel dan menggunakan semi pada tata rias pengantin Agung utama. Fungsi busana sebagai penutup badan dan dapat menutupi kekurangan atau aurat pada tubuh. Selain itu, busana juga dapat menonjolkan ciri khas suatu tata rias dengan menggunakan bentuk dan motif sesuai dengan kesempatan. Fungsi aksesoris sebagai sarana tambahan sebagai pelengkap dari busana yang dapat mempercantik diri seseorang dengan mempergunakan aksesoris sesuai kesempatan. Pada tata rias pengantin Agung Bali juga memiliki makna tersendiri sesuai dengan motifnya, simbolnya maupun lambang dari benda tersebut. Menurut Saussure (1994) mengungkapkan pengertian makna sebagai pengertian, lambang atau konsep yang dimiliki atau terdapat pada suatu tanda linguistik.

Pemaparan di atas menyatakan bahwa tata rias pengantin memiliki ciri khas tersendiri setiap Kabupatenya, begitupula pada tata rias pengantin Agung Jembrana memiliki ciri khas tersendiri yang dapat dilihat dari tata rias wajah, tatanan rambut busana serta aksesorisnya. Pada tatanan rambut identik dengan menggunakan semi yang disebut dengan semi capit udang dengan memiliki makna sebagai lambang keseimbangan. Bunga yang digunakan juga sangat berbeda dimana menggunakan bunga menori putih dengan memiliki makna sebagai kesucian. Busana yang digunakan pada tata rias pengantin Agung Jembrana menggunakan kain khas Jembrana yang dapat dilihat dari motif yang digunakan yaitu motif cerari dan mastuli penuh. Dari latar belakang yang telah diuraikan, maka peneliti akan melakukan penelitian dengan judul "Tata Rias Pengantin Agung Jembrana". penelitian ini bertujuan untuk mendeskripsikan bagaimana tata rias pengantin Agung Jembrana dan mendeskripsikan fungsi dan makna dari tata rias pengantin Agung Jembrana.

\section{METODE PENELITIAN}


Penelitian yang digunakan adalah penelitian deskriptif kualitatif. Penelitian ini bermaksud untuk mendefinisikan bahwa metode penelitian deskriptif adalah metode penelitian yang digunakan untuk menemukan pengetahuan yang seluasluasnya terhadap objek penelitian pada suatu masa tertentu. Penelitian ini bertujuan untuk mendeskripsikan bagaimana tata rias pengantin Agung Jembrana dan mendeskripsikan fungsi dan makna dari tata rias pengantin Agung Jembrana. Informan dari penelitian ini yaitu: Ibu Ni Ketut Sumiati selaku pemilik salon dan LKP W \& W Asri, Ibu Ni Ketut Rustianti, S.Sos selaku pemilik salon dan LKP Sekar Taji, dan penata rias yang mengatahui tata rias pengantin Agung Jembrana. Variabel dalam penelitian ini yaitu tata rias pengantin Agung Jembrana yang dilihat dari tata rias wajah, tatanan rambut, busana dan aksesoris serta fungsi dan makna dari setiap bagian-bagian tata rias pengantin Agung Jembrana. Metode yang digunakan yaitu metode observasi dan wawancara. Instrumen dalam penelitian ini adalah pedoman observasi digunakan untuk memperoleh gambaran umum terkait dengan tata rias pengantin Agung Jembrana yang terdiri dari tata rias wajah, tatanan rambut, busana dan aksesoris serta fungsi dan maknanya. Lembar wawancara berisi sejumlah pertanyaan yang akan diajukan kepada informan. Pedoman wawancara ini digunakan untuk memperoleh gambaran tentang tata rias pengantin Agung Jembrana. Metode dan Teknik analisis data yang digunakan dalam penelitian ini adalah teknik deskriptif, untuk mengetahui tentang tata rias wajah, tatanan rambut, busana dan aksesoris serta fungsi dan maknanya.

\section{HASIL DAN PEMBAHASAN Hasil}

Tata rias pengantin agung Jembrana merupakan tata rias yang terdiri dari tata rias pengantin agung utama yang digunakan pada saat acara pernikahaan dengan memiliki ciri khas tersendiri di kabupaten Jembrana yang dapat dilihat dari semi yang dinamakan dengan semi capit udang dengan menggunakan busana bludru hitam dan kamen menggunakan tenunan khas kabupaten Jembrana. Tata Rias Pengantin Agung Jembrana terdiri dari tata rias wajah, tatanan rambut, busana pengantin wanita dan pria serta aksesoris. Peneliti melakukan observasi di Puri, LKP dan salon serta penata rias. Peneliti melakukan wawancara dengan Ketua HARPI, Anggota HARPI serta penata rias yang mengetahui tentang tata rias pengantin Agung Jembrana sehingga peneliti mendapatkan informasi tentang tata rias tersebut.

Tata rias wajah pengantin Agung Jembrana terdiri dari serinata, alis-alis, eyeshadow, shading, lipstik dan blushon yang memiliki fungsi dan makna tersendiri. Seri artinya cantik dan Nata artinya agung. Jadi serinata merupakan ciri khas hiasan dahi yang digunakan pada pengantin Bali. Serinata di buat dengan menggunakan ukuran dan dibentuk sesuai dengan bentuk wajah setiap pengantin yang dibuat dengan menggunakan pensil alis warna hitam yang diarsir sesuai arah pertumbuhan rambut. Serinata memiliki makna yang terkandung di dalamnya adalah menandakan bahwa seorang telah dewasa dimana seseorang yang sudah menikah harus memiliki pemikiran yang dewasa dalam menjalani bahtera rumah tangga. Fungsi dari serinata yaitu sebagai hiasan dahi untuk membentuk dahi menjadi sempurna dan menambah keanggunan, kecantikan seorang pengantin. Alis pada pengantin Bali umumnya berbentuk alis daun intaran mempunyai ujung yang runcing dan panjang (nyurarit). Daun intaran dalam kehidupan sehari-hari adalah sebuah daun yang biasa saja, namun memiliki makna suatu ide yang universal dan abstrak tentang keindahan. Ujung alis yang meruncing tanpa ada batas diibaratkan keindahan kehidupan wanita bali yang tidak ada ujungnya, sedangkan pangkah alis dari besar ke kecil memiliki makna kehidupan dari yang berat sampai yang ringan. Alis-alis memiliki fungsi untuk mempercantik diri dan mempertajam alis itu sendiri. Hiasan mata atau eyeshadow merupakan hiasan mata yang memiliki fungsi sebagai perias pada kelopak mata, memberikan bayangan pada kelopak mata dan dapat mempertajam mata agar mata 
terlihat lebih hidup dan cantik. Warna eyeshadow yang digunakan pada pengantin Bali pada umunya menggunakan warna emas dan kuning atau sesuai dengan busana yang digunakan tetapi mengindari warna merah karena menurut kepercayaan masyarakat Bali khususnya penganut agama Hindu menganggap warna merah memiliki kesan dan arti yang negatif. Eyeshadow melambangkan kejayaan dan kemakmuran. Eyesahdow pada tata rias pengantian Agung Jembrana menggunakan eyeshadow hitam dan emas. Shading hidung tidak memiliki makna khusus, melainkan hanya memiliki fungsi sebagai penyamar atau menutupi bagian bagian agar terlihat tirus dan mendekati wajah oval. Perona pipi tidak memiliki makna khusus, melainkan hanya memiliki fungsi sebagai memberikan kesan lebih cerah pada bagian pipi agar pengantin terlihat semakin anggun dan cantik. Perona bibir tidak memiliki makna khusus, hanya saja memiliki fungsi sebagai pencerah pada bibir agar bibir terlihat lebih cantik dan berbentuk. Lipstick yang digunakan pada pengantin Agung Jembrana menggunakan warna merah muda dan warna merah. Untuk tata rias wajah pengantin pria tidak terlalu banyak menggunakan makeup hanya saja menggunakan makeup natural seperti alas bedak yang tipis sesuai dengan warna kulit, bedak yang natural, melakukan sedikit shading pada hidung, eyeshadow yang warna natural coklat atau emas agar serasi dengan pengantin wanita, menggunakan alis-alis sesuai dengan bentuk alisnya, eyeliner tipis dan lipstick yang menggunakan warna natural. Langkahlangkah dalam merias wajah sebagai berikut:

1. Pertama yang dilakukan untuk merias wajah pada pengantin wanita yaitu dengan membersihkan wajah dengan dengan menggunakan milk cleanser.

2. Lalu memberikan penyegar berfungsi sebagai penutup pori-pori wajah

3. Mengaplikasikan foundution sesuai warna kuning langsat untuk pengantin.

4. Kemudian lakukan shading pada bagian pipi, hidung dan rahang, selanjutnya aplikasikan bedak tabur kebagian seluruh wajah kemudian aplikasikan bedak padat agar riasan tidak mudah luntur.

5. Kemudian bentuk alis dengan menggunakan pensil alis dengan warna alis yaitu coklat kehitaman

6. Aplikasikan eyeshadow warna hitam pada chourge dan pada kelopak mata warna emas

7. Kemudian pasangkan bulu mata, selanjutnya aplikasikan eyeliner atas dan bawah dengan warna hitam, perona pipi dan lipstik yang terakhir.

Tatanan rambut pada tata rias pengantin Agung Jembrana pada pengantin wanita terdiri dari: semi capit udang, bunga menori putih, bunga menori putih kuncup, bunga bacangan, bunga emas, bunga kap, garuda mungkur, puspa lembo, sanggul gelung tanduk, bunga cempaka putih, kuning dan bunga sandat. Semi capit udang adalah semi khas pengantin Agung Jembrana yang memiliki makna sebagai lambang keseimbangan dimana ketika seseorang sudah menikah harus memiliki sikap seimbangan antara pikiran, tubuh dan jiwa. Semi capit udang memiliki fungsi sebagai penyeimbang dari tatanan rambut yang dibuat seperti menyerupai capit udang. Bunga menori putih adalah bunga yang sudah menjadi ciri khas pada pengantin Agung Jembrana yang memiliki makna sebagai lambang kesucian, begitupun seseorang harus tetap memiliki hati nurasi dan tetap rendah hati. Bunga menori putih memiliki fungsi sebagai penyanga bunga banjangan. Bunga menori kuncup putih adalah bunga yang dipasang sepanjang bentuk seinata dengan berjumlah 9 kuncup dengan memiliki makna sebagai lambang keindahan, dimana keindahan yang dimaksudkan yaitu seorang pengantin wanita akan terlihat lebih cantik dan anggun. Fungsi bunga menori kuncup putih sebagai keindahan yang dipasang sepanjang bentuk serinata dan dapat mempercantik tampilan dari pengantin. Bunga mawar merah dipasang pada bagian depan diantara juntaian bunga menori putih pada tata rias pengantin Agung Jembrana. Makna dari bunga mawar merah yaitu melambangkan kekuatan hati seorang wanita, begitupula seorang pengantin ketika sudah menikah harus tetap memiliki 
kekuatan hati dalam mengahadapi kehidupan baru. Bunga mawar merah berfungsi sebagai hiasan serta untuk mempercantik tampilan penataan rambut pengantin. Bunga cempaka putih dan kuning melambangkan samara dan ratih. Bunga cempaka putih, kuning, dan sandat memiliki makna yang melambangkan brahma, wisnu dan iswara. Ketiga bunga ini memiliki fungsi sebagai memberikan keharuman, kesegaran pada pengantin dan sebagai penutup sanggul. Bunga bancangan pada tata rias pengantin Agung Jembrana sama dengan bancangan pada tata rias pengantin Agung Badung. Bunga bancangan memiliki fungsi sebagai memperindah dan penyangga untuk membentuk segitiga dari bunga emas. Bunga emas yang digunakan tata rias pengantin Agung Jembrana sama dengan bunga emas pada tata rias pengantian Agung Badung. Bunga emas memiliki fungsi sebagai hiasan kepala yang dibentuk segitaga meruncing yang memiliki nilai keindahan dan terlihat lebih cantik. Bunga kap adalah hiasan tatanan rambut yang paling terakhir diletakkan paling tinggi. Bunga kap berfungsi sebagai penutup bunga emas bagian belakang. Puspa lembo adalah hiasan rambut yang posisinya di bagian sanggul belakang yang berfungsi sebagai penghias sanggul gelung tanduk. Puspa lembo tidak memiliki makna khusus, sanggul gelung tanduk yaitu sebagai simbol keberanian. Dimana lambang keberanian ini menandakan bahwa pengantin harus kuat dalam menghadapi kehidupan barunya. Sanggul gelung tanduk ini di jadikan ciri khas pada pengantin Jembrana karena pada zaman dahulu di Jembrana memiliki budaya mekepung-kepungan dimana sanggul gelung tanduk ini menyerupai tanduk kerbau. sanggul gelung tanduk yaitu sebagai simbol keberanian, dimana lambang keberanian ini menandakan bahwa pengantin harus kuat dalam menghadapi kehidupan barunya. Sanggul gelung tanduk ini di jadikan ciri khas pada pengantin Jembrana karena pada zaman dahulu di Jembrana memiliki budaya mekepungkepungan dimana sanggul gelung tanduk ini menyerupai tanduk kerbau. Langkahlangkah pembentukan tatanan rambut sebagai berikut:
1. Pertama bagi rambut menjadi dua bagian.

2. Bagian depan di bentuk semi dan pada bagian belakang diikat. Kemudian pasangkan rambut cemara kemudian bentuk rambut cemara itu dengan bentuk kerucut, rapikan.

3. Selanjutnya pasangkan bunga menori kembang pada bagian depan, selanjutnya pasangkan bancangan di atas bunga menori putih tadi, pasangkan bunga mawar merah, kemudian ambil bunga emas kemudian bentuk bunga emas yang berjumlah 21 sampai 25 tangkai dengan bentuk segitiga meruncing di mulai dari pemasangan bunga menori putih

4. Selanjutnya pemasangan bunga bancangan, selanjutnya pemasangan bunga mawar merah.

5. Kemudian pasangkan bunga emas yang $9,7,5,2,1,1$, kemudian terakhir pasang bunga kap pada bagian belakang yang berjumlah 1 tangkai. Selanjutnya pasang sanggul gelung tanduk pada bagian belakang

6. Kemudian pasangkan puspa lembo pada bagian sanggul gelung tanduk dipasang kanan dan kiri sanggul

7. Selanjutnya pasangkan bunga cempaka putih, kuning dan sandat di sebelah sanggul gelung tanduk. Terakhir garuda mungkur pada tengahtengah di belakang bunga kap

Busana merupakan busana yang digunakan dari ujung rambut sampai ujung kaki. Busana pada pengantin wanita terdiri dari: tapih wali, kamen songket bermotif mastuli penuh, selendang bersulam emas, selendang bermotif cerari, baju bludru hitam. Pada pengantin pria terdiri dari: kamen bermotif mastuli penuh, saput songket bermotif mastuli penuh, selendang bermotif cerari dan baju bludru hitam. Tapih wali memiliki makna sebagai memiliki makna sebagai lambang masa muda dari seorang pengantin dan fungsi tapih wali sebagai penutup kaki dan sebagai underwear. Kamen songket memiliki makna sebagai keindahan dan kemewahan pada mempelai pengantin dimana pengantin akan terlihat lebih mewah. Fungsi dari kamen songket 
adalah sebagai penutup dari tapih. Selendang bersulam benang emas adalah selendang yang digunakan pada bagian dada yang berfungsi sebagai penutup dada. Maka dari itu, selendang ini digunakan untuk melambangkan daerah tersebut memiliki ciri khas tersendiri akan keindahan tenunannya. Selendang bermotif cerari adalah selendang yang digunakan di bagian badan yang berfungsi sebagai penutup badan dan memperindah badan. Baju bludru hitam adalah busana yang digunakan pengantin wanita dan pria yang berfungsi sebagai penutup badan. Pada pengantin pria, Kamen mastuli penuh memiliki makna sebagai keagungan dan kewibawaan seorang raja begitupula, seorang pria akan terlihat lebih wibawa. Kamen songket atau saput adalah kamen yang digunakan setelah kamen mastulih penuh. Saput berfungsi sebagai penutup dan saput ini wajib ada dan digunakan pada pengantin pria. Selendang bermotif cerari (umpal) ini digunakan sebagai umpal yang digunakan sebagai hiasan atau pengerat dari saput dan dipasangkan di pinggang setelah saput. Umpal memiliki makna dari simbol Dewa Siwa dalam perwujudannya sebagai pengembali asalnya. Baju bludru hitam adalah busana yang digunakan pengantin pria maupun wanita berfungsi sebagai penutup badan. Langkah-langkah pemasangan busana pada pengantin wanita terdiri dari pertama menggunakan tapih wali, kamen songket bermotif mastuli penuh, selendang bersulam benang emas, selendang bermotif cerari dan baju bludru hitam. Pengantin pria terdiri dari pertama menggunakan kamen bermotif mastuli penuh, selanjutnya menggunakan saput bermotif mastuli penuh, selendang (umpal) cerari, terakhir baju bludru hitam.

Aksesoris adalah pelengkap dari busana. Aksesoris pengantin wanita terdiri dari: subeng, kalung binar, gelang nagastru dan sabuk pending. subeng menandakan keharmonisan pengetahuan dan sikap, sehingga mencegah sikap keegoisan begitupula seorang pengantin dapat menjaga sikap dan keegoisannya agar rumah tangga tetap bahagia dan harmonis. Berfungsi sebagai hiasan pada telinga. Kalung binar adalah perhiasan yang digunakan pada leher yang berjumlah 9 liotin yang melambangkan semakin banyak jumlah liotin sebagai tinggi tingkat status sosial seseorang tersebut. Fungsi dari kalung binar ini yaitu sebagai pelengkap. Sabuk pending adalah hiasan pada badan yang diletakkan pinggang yang berfungsi sebagai memperindah. Makna yang terkandung pada sabuk pending adalah melambangkan agar mampu mengikat atau membatasi diri sebagai seorang istri. Gelang nagasatru adalah hiasan pada tangan yang berfungsi sebagai pelengkap dengan makna melambangkan agar si pengantin dapat mengekang diri. Pada pengantin pria terdiri dari: rumbing, keris, gelang nagasatru dan gelang kaki. Rumbing adalah hiasan telinga yang digunakan pada pengantin pria, dengan makna yang terkandung pada rumbing adalah keharmonisan pengetahuan dan sikap, untuk mencegah sikap keegoisan begitupula seorang pengantin dapat menjaga sikap dan keegoisannya agar rumah tangga tetap bahagia dan harmonis. Berfungsi sebagai pelengkap. Keris dipakai oleh pengantin pria untuk menambah kegagahan, kebagusan dan wibawa bagi sipemakai. Makna lambang keris bagi suatu perkawinan merupakan lambang purusa dan pradana (laki-laki dan perempuan). Berfungsi sebagai hiasan yang digunakan pada bagian belakang. Gelang adalah salah satu aksesoris tubuh yang digunakan untuk menghias tangan. Gelang melambangkan agar si pengantin dapat mengekang diri. Bunga pucuk emas adalah hiasan kepala yang digunakan pada bagian udeng yang digunakan pada pengantin pria. Langkah penggunaan aksesoris pengantin wanita terdiri dari: subeng, kalung binar, sabuk pending, gelang nagasatru. Pengantin pria dimulai dari penggunaan rumbing, keris, gelang nagasatru terakhir gelang kaki.

\section{PEMBAHASAN}

Perbedaan tata rias wajah pengantin Agung Bali dengan tata rias wajah yang digunakan pada pengantin Agung Jembrana memiliki perbedaan 
dengan tata rias pengantin Bali Agung pada tata rias wajah (make up) yaitu pada serinata. Pada tata rias pengantin Agung Bali serinata menggunakan ukuran tetapi pada tata rias pengantin Agung Jembrana serinata di buat sesuai bentuk wajah pengantin. Tata rias pengantin Agung Jembrana merupakan tata rias cantik yang terdiri dari: serinata, hiasan mata (eyeshadow), perona bibir (lipstick) dan alis-alis.

Tatanan rambut pada tatanan
rambut pengantin Bali
menggunakan bunga sandat emas
sebagai bunga utamanya dan
menggunakan gelung kucit pada bagian belakang. Sedangkan tata rias rambut pengantin Kabupaten Jembrana terdiri dari: menggunakan bunga menori putih, bunga menori kuncup putih, bunga bancangan, bunga sandat emas, puspa lembo, bunga kap, garuda mungkur, bunga cemapaka kuning dan putih, bunga sandat dan sanggul gelung tanduk.

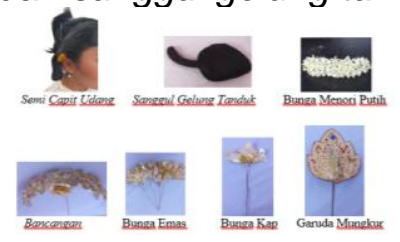

Gambar 3. Tatanan Rambut

Busana pengantin di Bali menonjolkan dari sebuah daerah tersebut dengan memiliki motif tersendiri yang merupakan kemewahan dari daerah itu. Sebuah busana menggambarkan sebuah maha karya yang penuh keindahan. Keragaman busana pengantin Bali pada masing-masing Kabupaten memiliki kharisma dan keanggunan yang dapat dilihat dari motif dan warna busananya. Busana pengantin wanita pada tata rias pengantian Bali Agung terdiri dari: tapih prada, kamen prade, betbet prade dan selendang. Sedangkan pada tata rias pengantin Agung Jembrana terdiri dari: tapih wali, kamen songket, selendang bersulam benang emas, selendang cerari dan baju bludru hitam. Sedangkan busana pria terdiri dari: tapih mastuli penuh, kamen songket, umpal cerari dan baju bludru hitam.

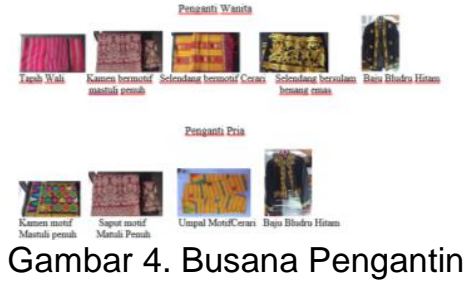

Pada aksesoris yang digunakan berupa aksesoris logam atau yang berasal dari bunga segar. Aksesoris yang digunakan pada tata rias pengantin Kabupaten Jembrana tidak jauh berbeda dengan aksesoris yang digunakan pengantin Bali Agung. Aksesoris tata rias pengantin Agung Jembrana terdiri dari: sabuk pending, subeng, gelang dan kalung binar. Sedangkan aksesoris pengantin pria meliputi: keris, gelang nagasatru dan kaki, bunga pucuk emas dan rumbing.

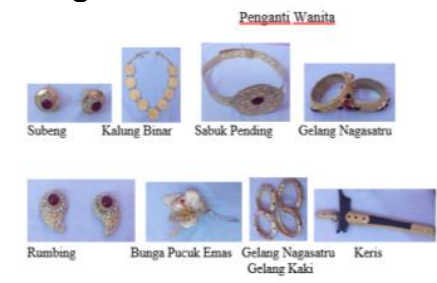

Gambar 5. Aksesoris Pengantin

Hasil penelitian oleh Ni Putu Delia Wulansari (2015) dengan judul "Bentuk, Fungsi, dan Makna Tata Rias dan Prosesi Upacara Perkawinan Bali Agung Di Bali menyatakan bahwa Bali mempunyai tradisi sendiri dalam melaksanakan upacara perkawinannya. Hal ini dinyatakan bahwa tatanan rambut pada pengantian Bali Agung terdiri dari: petitis tajuk, bunga sasak, bunga bancangan, puspa lembo, gelung agung, sandat emas, kap emas, garuda mungkur dan kompyong. Busana dan aksesorisnya terdiri dari: tapih, wastra perada, sabuk perada, cerik prada, badong, gelang kana, gelang naga satru, pending, subeng, dan cincin.

Selanjutnya hasil penelitian diperkuat kembali oleh Ni Putu Putri Astuti (2017) Tata Rias Pengantin Kabupaten Klungkung mengatakan bahwa: Hasil penelitian ini adalah: (1) tata rias pengantian Kabupaten Klungkung dibagi menjadi 4 bagian yaitu (a) tata rias wajah 
yaitu serinata, alis-alis, hiasan mata, hidung, perona pipi dan hiasan bibir. (b) tata rias rambut yaitu semi lilit/gulung, bunga sari konta, bunga mawar, cempaka putih, kuning, sandat, bunga reong emas, bunga kompyong, cucuk emas, sanggul kletek mandel,(c) busana pengantin, busana, busana wanita yaitu tapih pradal songket, wastra prada/songket, sabuk prada, selendang prada/songket, busana pria wastra lanang melencingan, saput prada/songket, umpal dan destar, (d) aksesoris, aksoris wanita sabuk bebekeng, subeng, gelang, cincin, tapel pelengan, aksesoris pria keris, bunga pucuk emas.

Hasil penelitian oleh Clarina Novi Olgaria (2017) dengan judul" Kajian Tata Rias Pengantin Tradisional Jember Sari Jawa Timur. Hasil Peneleitian menunjukkan bahwa bentuk tata rias pengantian tardisional Jember Sari sebagian besar terinspirasi dari hasil komoditi alam kota Jember yaitu tembakau. Tata rias wajah menggunakan alis dimana pertama menggunakan alis bewarna coklat kemudian finishing menggunakan pensil alis berwarna hitam. Riasan mata mengguanakn eyeshadow coklat dan orange. Kemudian pada blushon menggunakan warna orange dan lipstick menggunakan merah sirih.

Kadek Lina Wiartini (2016) dengan judul "Tata Rias Pengantin Agung Kabupaten Karangasem Provinsi Bali menyatakan bahwa langkahlangkah pelaksanaan dimulai dari tata rias wajah, selanjutnya pada tata rias rambut: pembentukan semi gopong, pusung kerucut, sanggul gento agung, bunga mawar, cempaka putih, cempaka kuning, blengker, bunga sandat, empakempak, bunga cempaka, cucuk bundar emas dan terakhir sekar taji. Langkah penggunaan busana pengantin wanita meliputi: penggunaan tapih, kamen songket, stagen, slendang blebet sutra cina dan terakhir selendang bangsing. Pada pengantin pria menggunakan: saput songker merebong, sabuk/stagen, kampuh/saput sutra penuh, umpal, baju bludru bersulam, dan destar. Langkah penggunaan aksesoris pengantin wanita meliputi: subeng cerorot, badong, gelang dan sabuk pending. Pada pengantin pria meliputi: penggunaan rumbing, gelang dan tahap akhir penggunaan bros. Pada tata rias pengantin ini yang menjadi ciri khasnya yaitu terletak pada selendang bangsingan yang dibuat dengan cara ditenun dengan ciri khas di kabupaten tersebut dan penataan bunga dan jenis bunga di sebut empak-empak yang berbeda dengan yang lainnya. Pernyataan di atas menyatakan memang setiap Kabupaten memiliki ciri khas tersendiri sesuai dengan tradisi dan keyakinan masyarakatnya.

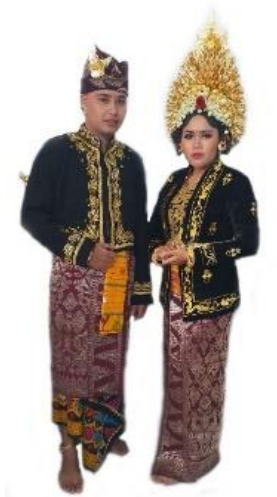

Gambar 6. Tata Rias Pengantin Agung Jembrana Sumber: Dokumentasi Pribadi

\section{KESIMPULAN}

Berdasarkan hasil penelitian yang dilakukan maka dapat disimpulkan sebagai berikut:

Bagian-bagian dari tata rias pengantin Agung Jembrana yang terdiri dari tata rias wajah, tatanan rambut, busana dan aksesorisnya dimana tata rias di setiap kabupatennya memiliki ciri khas tersendiri sesuai dengan peninggalan nenek moyang terhadulu dan sesuai dengan adat istiadat dari daerah masing-masing. Begitu pula pada tata rias pengantin Agung Jembrana memiliki ciri khas sendiri dan sangat berbeda dari tata rias pengantin di Kabupaten lain yang dapat dilihat dari segi tata rias wajah, tatanan rambut, busana dan aksesoris yang digunakan dimana busana tata rias ini memang kain ciri khas dari Kabupaten 
Jembrana yaitu khas tenunan Jembrana. Pada tatanan rambut juga khas menggunakan bunga menori putih. Berikut bagian - bagiannya:

Tata rias pengantin Agung Jembrana terdiri dari: tata rias wajah yang digunakan pada pengantin wanita terdiri dari: serinata, alis-alis, hiasan mata (eyeshadow), perona pipi (blush on), perona bibir (lipstick) dan shading wajah. Sedangkan pada pengantin pria tidak terlalu banyak menggunakan makeu up hanya saja menggunakan make up secara natural. Tatanan rambut terdiri dari: semi capit udang, sanggul gelung tanduk, bunga menori putih, bunga cempaka putih, kuning, sandat, bunga mawar, bunga menori kuncup pputih, bancangan, bunga emas, bunga kap, garuda mungkur dan puspa lembo. Pengantin pria terdiri dari udeng. Busana yang digunakan pada pengantin wanita terdiri dari: tapih wali, kamen songket, selendang cerari, selendang bersulam emas dan baju bludru hitam. Sedangkan pengantin pria terdiri dari: kamen mastuli penuh, saput atau kamen songket, umpal cerari dan baju bludru hitam. Aksesoris yang digunakan pada pengantin wanita terdiri dari: subeng, kalung binar, sabuk pending dan gelang nagasatru. Sedangkan pengantin pria terdiri dari: keris, rumbing, bunga udeng, gelang nagasatru dan gelang kaki. Bagian-bagian dari tata rias pengantin Agung Jembrana memiliki fungsi dan makna tersendiri.

\section{SARAN}

Berdasarkan pembahasan hasil penelitian dan kesimpulan, maka dapat diajukan saran sebagai berikut:

1. Untuk masyarakat: agar masyarakat tetap mempertahankan tata rias pengantin Agung Jembrana tanpa meninggalkan pakem dari tata rias ini.

2. Para penata rias yang ada di Kabupaten Jembrana agar ikut serta tetap mempertahankan tata rias pengantin Agung Jembrana dengan cara mensosialisasikan, memperkenalkan kepada masyarakat
Jembrana dan masyarakat umum di Provinsi Bali.

\section{DAFTAR RUJUKAN}

Astuti, Putri“Tata Rias Pengantin Kabupaten Klungkung. e-journal Bosaparis Vol 8, Universitas Pendidikan Ganesha, No 2. 2017

Ari Safitri, Rizki. "Tata Rias Pengantin Agung Gaya Buleleng". e-journal Bosaparis Universitas Pendidikan Ganesha, Vol 8, No 2. 2017

Delia, Wulansari. 2015. "Bentuk, Fungsi dan Mkana Tata Rias dan Prosesi Upacara Perkawinan Bali Agung di Bali. e-Journal. Volume 04. Nomor 02 Tahun 2015. Universitas Negeri Surabaya.

Lina Wiartini, Ni Kadek" Study tentang Tata Rias Pengantin Agung Kabupaten Karangasem Provinsi Ball'. e-Journal Bosaparis Universitas Pendidikan Ganesha, Vol 4, No 1. 2016.

Mertami, Nyonya . 1993. Tata Rias Pengantin Bali: PT. UPADA SASTRA.

Pujiastuti, Dwi. 2016. "Tata Rias dan Busana Pengantin Bali Gaya Badung". e-journal Bosaparis Universitas Pendidikan Ganesha 2016.

Ferdinand de Saussure. 1994. Pengantar semantik. Tersedia pada https://susandi.wodpres.com/seputa r-bahasa/semantik/ (dikunjungi pada tanggal 7 juli 2018).

httpps://www.weddingku.com. (dikunjungi pada tanggal (11 Desember 2018)

Novi, Clarina. 2015. "Kajian Tata Rias Pengantin Tadisional Jember Sari Jawa Timur". e-Journal Universitas Negeri Surabaya.

Noviana, Mila. 2015. Hubungan Pengetahuan Rias Wajah Seharihari Dengan Menggunakan 
Jurnal Bosaparis: Pendidikan Kesejahteraan Keluarga

Volume 10, Nomor 2, Juli 2019

Kosmetika Tata Rias Wajah Di

SMK Negeri 3 Klaten. e-journal

Keluarga Vol 1, No 2. 2015 